\title{
Earthworm distribution and abundance predicted by a process-based model
}

Article

Published Version

Creative Commons: Attribution 3.0 (CC-BY)

Open Access

Johnston, A. S. A., Holmstrup, M., Hodson, M. E., Thorbek, P., Alvarez, T. and Sibly, R. M. (2014) Earthworm distribution and abundance predicted by a process-based model. Applied Soil Ecology, 84. pp. 112-123. ISSN 0929-1393 doi:

https://doi.org/10.1016/j.apsoil.2014.06.001 Available at https://centaur.reading.ac.uk/37865/

It is advisable to refer to the publisher's version if you intend to cite from the work. See Guidance on citing.

To link to this article DOI: http://dx.doi.org/10.1016/j.apsoil.2014.06.001

Publisher: Elsevier

All outputs in CentAUR are protected by Intellectual Property Rights law, including copyright law. Copyright and IPR is retained by the creators or other copyright holders. Terms and conditions for use of this material are defined in the End User Agreement.

\section{www.reading.ac.uk/centaur}

\section{CentAUR}

Central Archive at the University of Reading 
Reading's research outputs online 


\title{
Earthworm distribution and abundance predicted by a process-based model
}

\author{
A.S.A. Johnston ${ }^{\mathrm{a}, *}$, M. Holmstrup ${ }^{\mathrm{b}}$, M.E. Hodson ${ }^{\mathrm{c}}$, P. Thorbek $^{\mathrm{d}}$, T. Alvarez $^{\mathrm{e}}$, R.M. Sibly $^{\mathrm{a}}$ \\ a School of Biological Sciences, University of Reading, UK \\ ${ }^{\mathrm{b}}$ Department of Bioscience, Aarhus University, Denmark \\ c Environment Department, University of York, UK \\ d Environmental Safety, Syngenta Ltd., Bracknell, UK \\ e EcoRisk Solutions Ltd., Norwich, UK
}

\section{A R T I C L E I N F O}

\section{Article history:}

Received 25 March 2014

Received in revised form 11 June 2014

Accepted 16 June 2014

Available online 19 July 2014

\section{Keywords:}

Individual based model

Earthworm

Energy budget

Food availability

Soil water potential

Local movement

\begin{abstract}
A B S T R A C T
Earthworms are significant ecosystem engineers and are an important component of the diet of many vertebrates and invertebrates, so the ability to predict their distribution and abundance would have wide application in ecology, conservation and land management. Earthworm viability is known to be affected by the availability and quality of food resources, soil water conditions and temperature, but has not yet been modelled mechanistically to link effects on individuals to field population responses. Here we present a novel model capable of predicting the effects of land management and environmental conditions on the distribution and abundance of Aporrectodea caliginosa, the dominant earthworm species in agroecosystems. Our process-based approach uses individual based modelling (IBM), in which each individual has its own energy budget. Individual earthworm energy budgets follow established principles of physiological ecology and are parameterised for $A$. caliginosa from experimental measurements under optimal conditions. Under suboptimal conditions (e.g. food limitation, low soil temperatures and water contents) reproduction is prioritised over growth. Good model agreement to independent laboratory data on individual cocoon production and growth of body mass, under variable feeding and temperature conditions support our representation of $A$. caliginosa physiology through energy budgets. Our mechanistic model is able to accurately predict $A$. caliginosa distribution and abundance in spatially heterogeneous soil profiles representative of field study conditions. Essential here is the explicit modelling of earthworm behaviour in the soil profile. Local earthworm movement responds to a trade-off between food availability and soil water conditions, and this determines the spatiotemporal distribution of the population in the soil profile. Importantly, multiple environmental variables can be manipulated simultaneously in the model to explore earthworm population exposure and effects to combinations of stressors. Potential applications include prediction of the population-level effects of pesticides and changes in soil management e.g. conservation tillage and climate change.
\end{abstract}

(c) 2014 Elsevier B.V. All rights reserved.

\section{Introduction}

Earthworms are major contributors to soil biodiversity, are significant ecosystem engineers in terrestrial soils, and represent a large component of the stock of natural soil capital from which a range of ecosystem services flow (Keith and Robinson, 2012; Blouin et al., 2013). Earthworms can bring c. 40 t/ha/year of soil to the surface by casting and potentially change erosion rates by

\footnotetext{
* Corresponding author at: Room 405, Philip Lyle Building, School of Biological Sciences, University of Reading, Reading, Berkshire RG6 6AS, UK.

Tel.: +4401183785049.

E-mail address: a.s.a.johnston@pgr.reading.ac.uk (A.S.A. Johnston).
}

increasing surface roughness (Feller et al., 2003). Below ground, earthworms create soil aggregates which maintain soil structure, aid plant growth and promote carbon sequestration (e.g. Le Bayon et al., 2002; Butenschoen et al., 2009). Earthworms are also an important component of the diet of many European animal species, both vertebrate and invertebrate (Granval and Aliaga, 1988), and so are significant in ecosystem food chains. Thus, an ability to predict the spatiotemporal abundance of earthworm populations has important applications in forecasting how changing environmental conditions alter the provision of soil ecosystem services. However, previous models have neglected the major ecological drivers affecting earthworm populations in natural environments (e.g. movement in the soil, soil temperature, soil moisture and resources) (Schneider and Schröder, 2012). 
To predict how populations respond to environmental changes, understanding is needed of how the underlying life cycle processes of individuals are altered by ecological factors present in field conditions. Food supply is well recognised as a major factor limiting animal populations (Solomon, 1949; Sinclair, 1989) and is instrumental in structuring earthworm communities (Curry, 2004). Both the quantity and the quality of the food supply are important (Lee, 1985). For example, earthworm population abundance in the field has been found to vary in response to changes in soil organic matter (SOM) content, associated with habitat quality and land management practices (e.g. Edwards and Bohlen, 1996; El-Duweini and Ghabbour, 1965; Hendrix et al., 1992). Soil moisture is also a key factor in determining the abundance and distribution of earthworm populations (Lee, 1985). Clear relationships between soil water potential and earthworm physiology ( $A$. caliginosa activity, growth and reproduction rates) were identified by Holmstrup (2001). In the field, Gerard (1967) demonstrated how soil water potential governed the vertical movement of earthworm populations in the soil profile.

Understanding the links between environmental factors and population dynamics is not possible using classical population models (e.g. matrix models) as these consider populations as collective entities and landscapes as homogeneous (DeAngelis and Mooij, 2005). However, aiming to capture biological realism often results in models which are complex, require extensive parameterisation, are hard to evaluate and become species- and site-specific (Grimm et al., 2005). Instead, key drivers of the system should be integrated with generic frameworks explaining biological responses. This requires a process-based approach (Evans et al., 2013).

A process-based approach ideally begins by modelling how individual physiological processes relate to external environmental drivers through energy budgets. Individual based models (IBMs) can then be used to simulate the interactions between individuals and their environments, from which population dynamics emerge (Grimm and Railsback, 2012). Combining these approaches is necessary to mechanistically extrapolate from individual life history to population dynamics in realistic environments (e.g. Sibly et al., 2013). The resulting models can then be used to analyse population responses to a variety of environmental conditions and land management practices through manipulation of landscape variables.

A process based model of earthworm populations would be particularly beneficial to agro-ecosystems, where the functions provided by earthworm activity are replaced by chemical and mechanical practices (Chan, 2001). Previous earthworm models have largely concentrated on easily reared species of importance in toxicity testing, vermiculture and waste management (e.g. Jager et al., 2006; Hobbelen and van Gestel, 2007; Johnston et al., 2014). However, the earthworm species considered are not commonly found in agricultural landscapes (Paoletti, 1999). Earthworm species inhabiting agricultural habitats are normally adapted to low quality food resources and regular periods of food limitation. The endogeic earthworm A. caliginosa is the dominant earthworm in arable soils (Riley et al., 2008) and its global distribution is wider than that of other species (Blakemore, 2002). Here we construct an energy-budget IBM for A. caliginosa and investigate the potential of this process-based approach to predict life histories and population dynamics under variable soil temperature, soil moisture and resource conditions in the laboratory and field. Although agricultural land management scenarios are not simulated here, we aim to capture the mechanisms governing the spatiotemporal distribution and abundance of $A$. caliginosa populations in field conditions, so that future exploration of agricultural management effects can be better understood. For example, the effects of pesticides on earthworm populations are routinely tested in pasture (SANCO, 2002), and so it is important to understand these systems for applications to ecological risk assessment.

\section{Methods}

The purpose of the model is to simulate $A$. caliginosa population dynamics under varying environmental conditions, representative of those encountered in the field, particularly food availability and quality, soil water conditions and soil temperature. Population dynamics emerge from environmental conditions constraining energy allocation amongst individuals; the way this happens is represented by an individual based model (IBM) in which each individual has its own energy budget. Here we give an outline summary of the model. A full description, following the ODD protocol for describing IBMs (Grimm et al., 2010) is presented in Appendix A in Supplementary material and Johnston et al. (2014) for Eisenia fetida. The model is implemented in Netlogo 5.0.4 (Wilensky, 1999), a platform for building IBMs.

\subsection{Energy budget model}

Individuals assimilate energy from ingested food and expend available energy on maintenance, growth and reproduction in the order of priority outlined in Fig. 1.

The energy budget model was parameterised for A. caliginosa with data relating to species-specific growth and reproduction rates under optimal environmental conditions as shown in Table 1. Sub-optimal feeding, temperature and soil water conditions then reduce metabolic rates. If food is limiting, the amount of food available in a patch $\left(\mathrm{g} / 0.01 \mathrm{~m}^{2}\right)$ is divided between the individuals living there. A proportion of ingested energy, determined by the energy content of food $\left(E_{x}\right)$ and assimilation efficiency $\left(A_{e}\right)$, becomes available for allocation to the various processes outlined in Fig. 1. $E_{x}(\mathrm{~kJ} / \mathrm{g})$ varies depending on the diet of the individuals whilst $A_{e}$ is assumed to be constant. If less energy is available than is required for maximum reproduction or growth then priorities operate as in Fig. 1 and reproduction and/or growth are reduced accordingly. Temperature alters individual metabolic rates according to the Arrhenius function (Fig. 1).

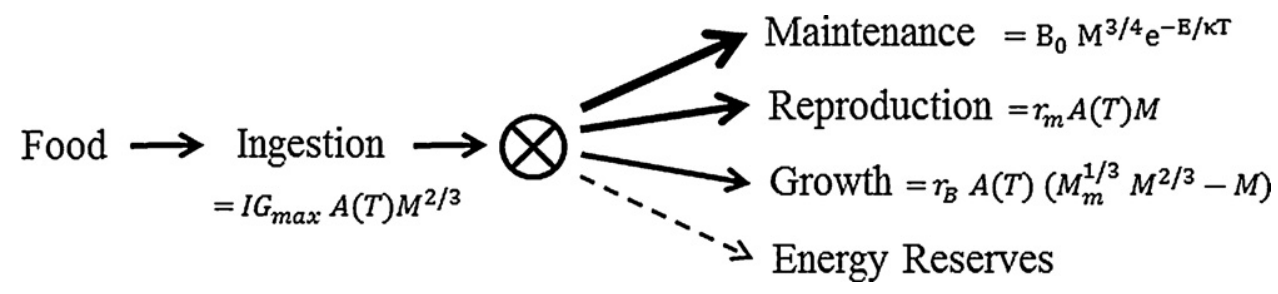

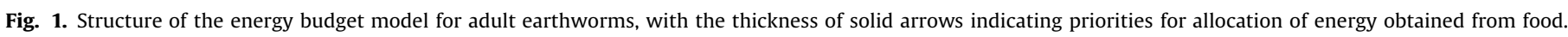

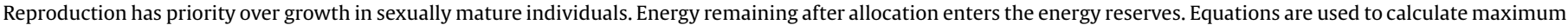

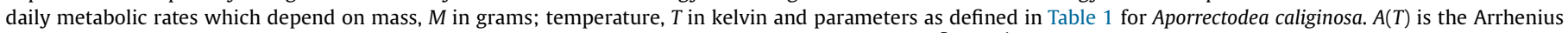
function of temperature, $A(T)=e^{-E / \kappa\left(1 / T-1 / T_{\text {ref }}\right)}$, where $\kappa$ is the Boltzmann's constant $\left(8.62 \times 10^{-5} \mathrm{eV} \mathrm{K}^{-1}\right)$. 
Table 1

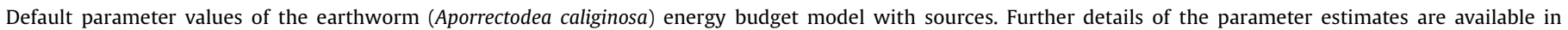
Appendix B of the Supplementary material.

\begin{tabular}{|c|c|c|c|c|c|}
\hline Symbol & Definition & Value & Unit & Reference & Notes \\
\hline$A_{e}$ & Assimilation efficiency & 0.19 & - & Lavelle and Spain (2001) & p. 470 \\
\hline$B_{o}$ & $\begin{array}{l}\text { Taxon-specific normalization } \\
\text { constant }\end{array}$ & 968 & $\begin{array}{l}\mathrm{kJ} / \mathrm{g} / \\
\text { day }\end{array}$ & Meehan (2006) & Calculated from Table 2, p. 881 and Eq. (4) \\
\hline$E$ & Activation energy & 0.25 & $\mathrm{eV}$ & Meehan (2006) & p. 880 \\
\hline$E_{c}$ & Energy content of tissue & 7 & $\mathrm{~kJ} / \mathrm{g}$ & Peters (1983) & p. 235 \\
\hline$E_{s}$ & Energy cost of synthesis & 3.6 & $\mathrm{~kJ} / \mathrm{g}$ & Sibly and Calow (1986) & Calculated from p. $54-55$ \\
\hline$E_{x}$ & Energy content of food & $\begin{array}{l}0.56- \\
21.2\end{array}$ & $\mathrm{~kJ} / \mathrm{g}$ & $\begin{array}{l}\text { Range depends on diet. See section } 2.3 \text { and } \\
2.4 .2 \text { for details. }\end{array}$ & \\
\hline $\mathrm{IG}_{\max }$ & Maximum ingestion rate & 0.805 & $\begin{array}{l}\text { g/day/ } \\
\mathrm{g}^{2 / 3}\end{array}$ & Taylor and Taylor (2014) & Table 1, p. 181 \\
\hline$M_{b}$ & Mass at birth & $\begin{array}{l}0.005- \\
0.026\end{array}$ & $\mathrm{~g}$ & Pedersen and Bjerre (1991) & $\begin{array}{l}\text { Calculated via linear regression with mass of } \\
\text { cocoon. See Appendix B }\end{array}$ \\
\hline$M_{c}$ & Mass of cocoon & $\begin{array}{l}0.008- \\
0.035\end{array}$ & $\mathrm{~g}$ & $\begin{array}{l}\text { Boström and Lofs-Holmin (1986); Boström } \\
\text { (1987) }\end{array}$ & $\begin{array}{l}\text { Calculated via linear regression with adult mass ( } \mathrm{g} \text { ). } \\
\text { See Appendix B }\end{array}$ \\
\hline$M_{p}$ & Mass at sexual maturity & 0.50 & $\mathrm{~g}$ & Lofs-Holmin (1983) & Fig. 6 , p. 35 \\
\hline$M_{m}$ & Maximum asymptotic mass & 2.00 & g & Lofs-Holmin (1983) & Fig. 1, p. 32 \\
\hline$r_{B}$ & Growth constant & 0.049 & /day & Lofs-Holmin (1983) & Fig. 6, p. 35 \\
\hline$r_{m}$ & $\begin{array}{l}\text { Maximum rate of energy allocation to } \\
\text { reproduction }\end{array}$ & 0.054 & $\begin{array}{l}\mathrm{kJ} / \mathrm{g} / \\
\text { day }\end{array}$ & Spurgeon et al. (2000) & Table 2, p. 1803 \\
\hline$T_{0}$ & Incubation period & 62 & days & Holmstrup et al. (1991) & Table 1, p. 181 \\
\hline$T_{r e f}$ & Reference temperature & 288.15 & kelvin & Eriksen-Hamel and Whalen (2006) & Fig. 1, p. 211 \\
\hline$\mu$ & Background mortality rate & 0.14 & $\% /$ day & & p. 210 \\
\hline
\end{tabular}

Metabolic processes have associated energetic costs: the energy cost of producing one cocoon is calculated as: $M_{c}\left(E_{c}+E_{s}\right)$ (Table 1$)$, where $M_{c}$ is mass of the cocoon, calculated together with $M_{b}$ by regression as described in Appendix B. Cocoon mass is linearly related to the mass of the reproducing adult whilst mass at birth depends on the mass of the cocoon (minimum to maximum ranges are presented in Table 1). Energy costs of movement are assumed to be included as part of "maintenance". Some of the studies used to parameterise the energy budget model are of $A$. turberculata, previously considered a sub-species of $A$. caliginosa (e.g. Perez-
Losada et al., 2009). Here we do not distinguish between these two species as they are closely related.

If any assimilated energy remains after expenditure to relevant life cycle processes it is stored in an individual's energy reserves, which may be utilised as an energy source when food is not available to pay the energy costs of maintenance and reproduction. Maximum energy reserves are proportional to an individuals mass and are taken to be $(M / 2) E_{c}$. Below a critical energy reserve threshold $\left((M / 4) E_{c}\right)$, individual's catabolise tissue for energy, resulting in weight loss proportional to an individual's

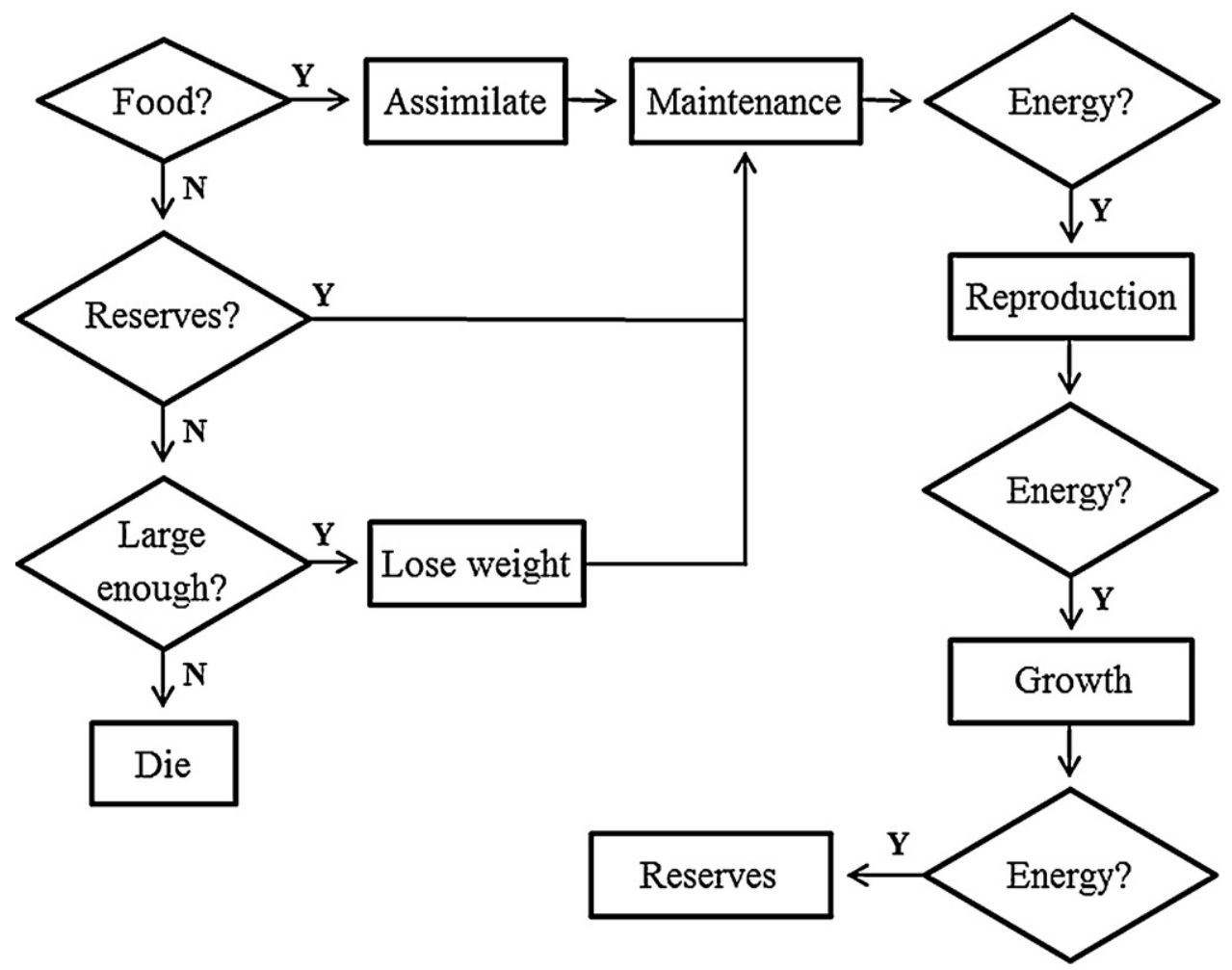

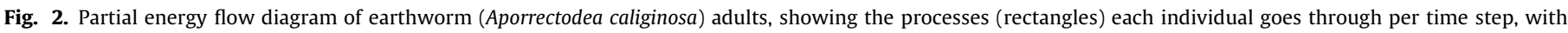

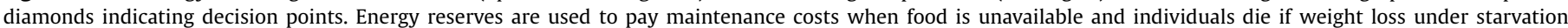
continues. 
maintenance costs. An individual dies of starvation if its energy reserves are depleted (Fig. 2).

\subsection{Individual based model}

The IBM comprises $A$. caliginosa individuals and a model soil profile consisting of two-dimensional $0.01 \mathrm{~m}^{2}$ patches of soil. In simulations of laboratory experiments, patches represent the horizontal soil surface, whilst in the field they represent a vertical cross-section of the soil profile. Individuals are characterized by life cycle stage (cocoon, juvenile or adult), mass and energy reserves, and patches by food availability, food quality, soil temperature, soil water content and soil texture. The model proceeds in discrete daily time-steps, at the end of which individual and patch variables are updated. Juvenile and adult movement between patches depends on food availability and soil water conditions in the soil profile, outlined in the "Movement" section below. Variation in food availability between patches arises from the movement and feeding of individuals in the soil profile. Soil water potential constrains individual ingestion rates and determines the onset of a resting phase (aestivation), outlined in the "Soil water potential" and "Aestivation" sections below.

\subsubsection{Soil water potential}

Holmstrup (2001) found decreasing soil water potentials to have a negative effect on individual $A$. caliginosa life cycle traits, as shown in Fig. 3. Here we suppose soil water potential $(\psi)$ reduces the ingestion rate parameter $\left(\mathrm{IG}_{\max }\right)$ as:

$\mathrm{IG}_{\max }(\psi)=\left(\mathrm{IG}_{\max }\right) e^{k \psi}$

where $\mathrm{IG}_{\max }$ is the parameter value at a soil water potential of $-2 \mathrm{kPa}$ (Table 1 ) and $k$ takes the value 0.040 . This results in less energy being available for allocation to growth or reproduction, than under optimal conditions of soil water potential $(-2 \mathrm{kPa})$. Fig. 3 presents model results when the model was set up as in Holmstrup (2001). Full details and results of the model simulations are available in Appendix C.

\subsubsection{Aestivation}

Holmstrup (2001) reported aestivation in A. caliginosa to be induced at soil water potentials in the range -19 to $-29 \mathrm{kPa}$ at a constant temperature of $15^{\circ} \mathrm{C}$, whilst Doube and Styan (1996) found the closely related species $A$. trapezoides to avoid soil water potentials below $-25 \mathrm{kPa}$. Here, we assumed a soil water potential of $-25 \mathrm{kPa}$ triggers aestivation, independent of temperature (e.g. Edwards and Bohlen, 1996). As facultative diapause is a condition that may terminate as soon as soil conditions become favourable (Lee, 1985), we assumed a soil water potential of $-20 \mathrm{kPa}$ prompts the re-emergence of individuals from aestivation. During

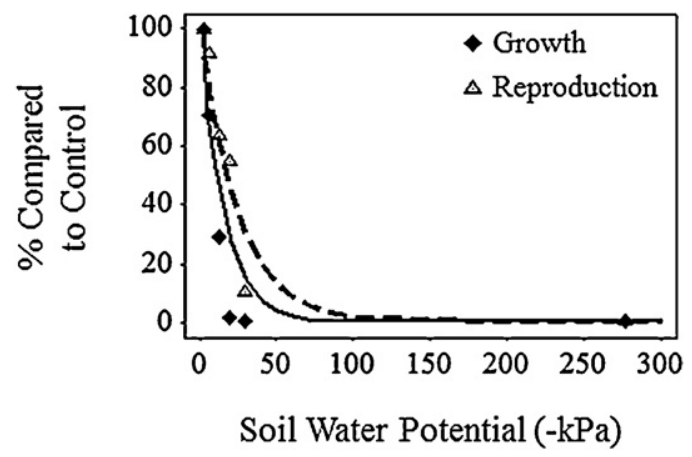

Fig. 3. The effects of soil water potential (less than $-2 \mathrm{kPa}$ ) on growth and reproduction of the earthworm Aporrectodea caliginosa, with data (points) from Holmstrup (2001) together with model simulation outputs (lines) for reproduction (dashed) and growth (solid).

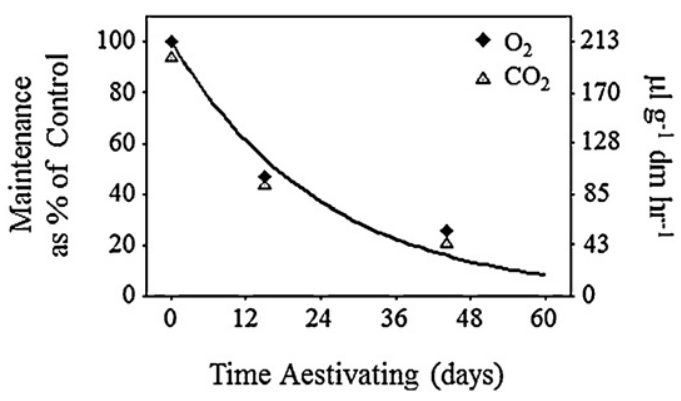

Fig. 4. Modelled decline in maintenance rates of the earthworm Aporrectodea caliginosa with time aestivating (line and left-hand axis) compared to oxygen consumption and carbon dioxide release data from Bayley et al. (2010) (points and right-hand axis).

aestivation, individuals utilize energy reserves to pay the energetic costs of maintenance according to the relationship between oxygen consumption and carbon dioxide release of $A$. caliginosa at different stages of aestivation recorded by Bayley et al. (2010) (Fig. 4)

\subsubsection{Movement}

Major factors determining the local movement of $A$. caliginosa in natural soil environments are soil water content and food quality (Lee, 1985). As A. caliginosa is sensitive to decreasing soil water potentials, the movement of individuals through the soil profile is primarily driven by soil water gradients when surface conditions are dry (Gerard, 1967). We assume that below a sub-optimal soil water potential of $-10 \mathrm{kPa}$ (e.g. growth and reproduction are not affected at $-10 \mathrm{kPa}$ in Holmstrup (2001)), individual movement is driven by the availability of higher soil water potentials in neighbouring patches in the model soil profile (Fig. 5). Burrowing activity of $A$. caliginosa in the top $10 \mathrm{~cm}$ of the soil profile is believed to reflect the presence of a higher SOM content (Jégou et al., 1998). Thus, if soil water conditions are non-limiting (greater than $-10 \mathrm{kPa}$ ) individuals preferentially move to patches of greater food quality, represented by the parameter $E_{x}$ (Fig. 5). Neighbouring patches occur both vertically and horizontally and if they do not provide better or worse conditions individuals move randomly.

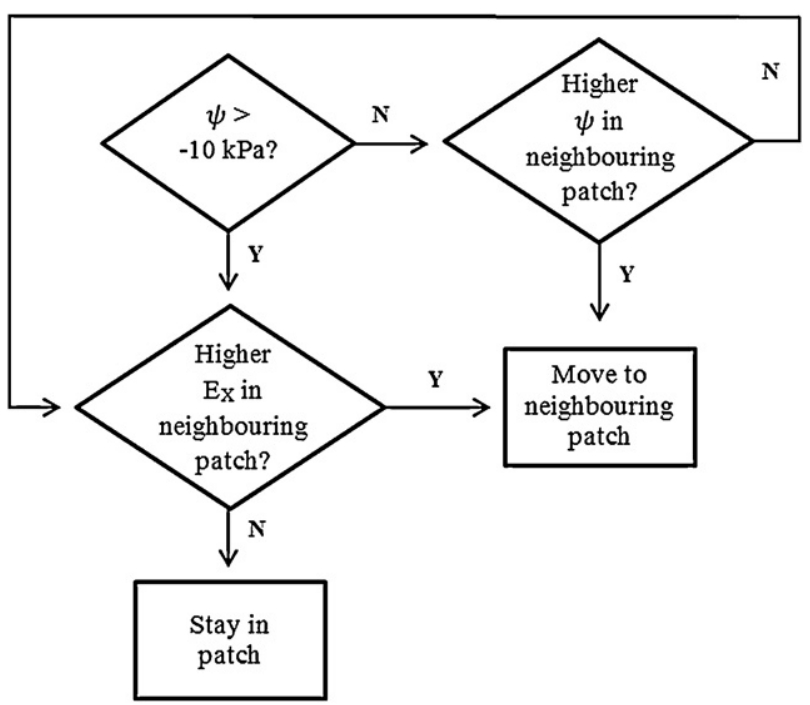

Fig. 5. Conceptual model of earthworm (Aporrectodea caliginosa) movement in the individual based model, where $\psi$ represents soil water potential and $E_{x}$ the energy content of food. Diamonds indicate decision points and rectangles are processes per daily time-step. 
Table 2

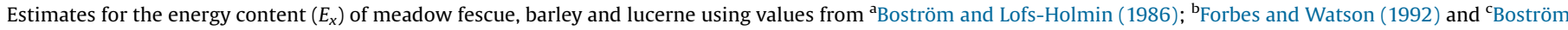
(1987). CP is crude protein, EE is ether extract (mainly lipids), CF is crude fibre and NFE is nitrogen-free extract (mg/g dry matter).

\begin{tabular}{|c|c|c|c|c|c|c|}
\hline & \multicolumn{4}{|c|}{ Analysis of dry matter (mg/g DM) } & \multirow[t]{2}{*}{ Digestible portion (\%) } & \multirow{2}{*}{$\begin{array}{l}E_{x} \\
(\mathrm{~kJ} / \mathrm{g})\end{array}$} \\
\hline & $\mathrm{CP}$ & $\mathrm{EE}$ & $\mathrm{CF}$ & NFE & & \\
\hline Meadow fescue & $140^{\mathrm{a}}$ & $26^{\mathrm{b}}$ & $280^{\mathrm{a}}$ & $493^{\mathrm{b}}$ & $56.4^{c}$ & 10.42 \\
\hline Barley & $180^{\mathrm{a}}$ & $16^{\mathrm{b}}$ & $230^{\mathrm{a}}$ & $392^{\mathrm{b}}$ & $30.4^{\mathrm{c}}$ & 4.93 \\
\hline Lucerne & $150^{\mathrm{a}}$ & $22^{\mathrm{b}}$ & $340^{\mathrm{a}}$ & $402^{\mathrm{b}}$ & $43.8^{\mathrm{c}}$ & 7.91 \\
\hline
\end{tabular}

Table 3

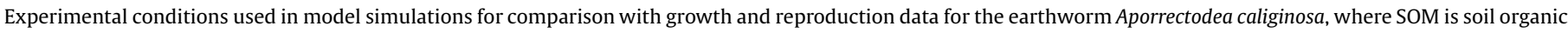
matters and $E_{x}$ is energy content of food.

\begin{tabular}{|c|c|c|c|c|c|c|}
\hline Study & Number of individuals & Food resource & $\operatorname{SOM}(\%)$ & $E_{x}(\mathrm{~kJ} / \mathrm{g})$ & Food quantity (g) (day provided) & Temp $\left({ }^{\circ} \mathrm{C}\right)$ \\
\hline Boström and Lofs-Holmin (1986) & 10 & Barley & 7 & 1.33 & $252(0)$ & 15 \\
\hline Boström (1987) & 1 & Meadow fescue & 5 & 1.018 & $252(0)$ & 15 \\
\hline Springett and Gray (1992) & 1 & Standard mix & 10 & 1.86 & $40(0)$ & 12 \\
\hline Lofs-Holmin (1983) & 5 & Manure & 10 & 5.76 & $20(0) 40(30) 80(60)$ & 15 \\
\hline Boström (1988) & 5 & Meadow fescue & 5.4 & 1.70 & $260(0)$ & 15 \\
\hline Boström (1988) & 5 & Lucerne & 5.4 & 1.64 & $260(0)$ & 15 \\
\hline Boström (1988) & 5 & Barley & 5.4 & 1.56 & $260(0)$ & 15 \\
\hline Boström and Lofs-Holmin (1996) & 5 & Meadow fescue & 5 & 1.02 & $1010(0)$ & $5,10,15$ \\
\hline
\end{tabular}

\subsection{Laboratory experiment simulations}

The model was set up to mimic the conditions of published laboratory experiments, for comparisons between modelled $A$. caliginosa growth and reproduction $(N=10)$ and data. Estimates of the energy content of food $\left(E_{x}\right)$ were needed for meadow fescue, barley and lucerne and these were based on the formula:

$E_{x}=\frac{(2.3 \mathrm{CP}+4.1 \mathrm{EE}+1.9 \mathrm{CF}+1.8 \mathrm{NFE})}{100}$

where $\mathrm{CP}$ is crude protein, $\mathrm{EE}$ is ether extract (mainly lipids), $\mathrm{CF}$ is crude fibre and NFE is nitrogen-free extract, measured in $\mathrm{mg} / \mathrm{g}$ dry matter (Forbes and Watson, 1992). Parameter values for Eq. (2) were derived from Boström and Lofs-Holmin (1986) and Forbes and Watson (1992) (Table 2). Boström (1987) recorded the relative mass of particle fractions for each plant material. Here, we took particle lengths $<0.5 \mathrm{~mm}$ to be digestible, following observations by Lowe and Butt (2003).

Well-composted cattle manure was provided as food in some experiments. Following Gunadi et al. (2002)'s observations that pre-composting for 5 weeks led to a $45 \%$ decline in reproduction rates of E. fetida, we assumed that the energy content of wellcomposted cattle manure was one third that of fresh manure. Wang et al. (2011) recorded the energy content of fresh manure to be approximately $21.2 \mathrm{~kJ} / \mathrm{g}$, giving an $E_{x}$ value of $7 \mathrm{~kJ} / \mathrm{g}$ for wellcomposted manure. The energy content of the soils in the experiments was calculated assuming that soil organic matter (SOM) has an energy content of $18.62 \mathrm{~kJ} / \mathrm{g}$ (Loustau, 1984). Table 3 outlines the conditions used in the experiments simulated here.

\subsection{Field trial simulations}

To investigate the model's ability to predict earthworm population responses to land management, we simulated $A$ caliginosa population dynamics in a field experiment by Gerard (1967) at Rothamsted, UK and Knight et al. (1992) at North Wykes Farm, UK. Gerard (1967) measured the vertical distribution and population structure (adult, juvenile and cocoon density) of $A$. caliginosa in the top $45 \mathrm{~cm}$ of soil under pasture. Knight et al. (1992) placed artificial cow pats on permanent grazed pasture and measured the earthworm biomass response, where $A$. caliginosa were the dominant earthworm species. The model soil profile

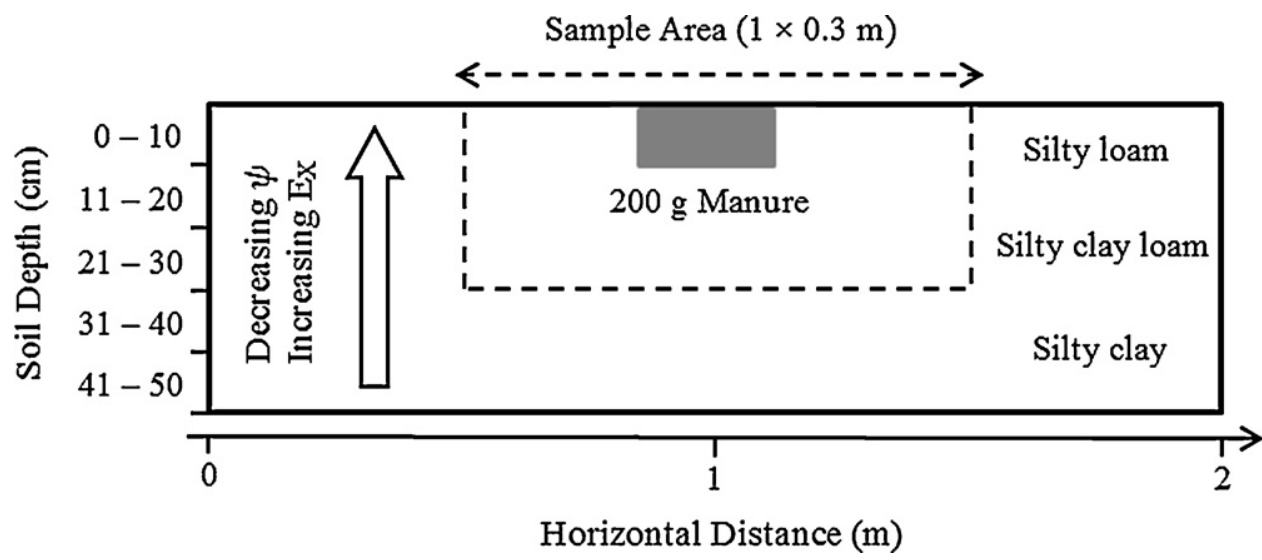

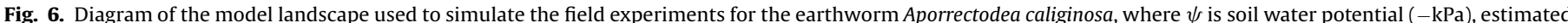

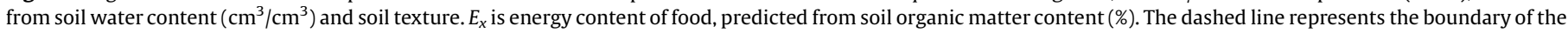

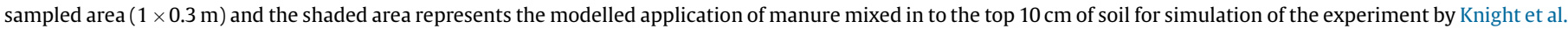
(1992). 
Table 4

Parameter values for estimating the soil water potential of different soil textures. $\theta_{\mathrm{r}}$ is the residual water content, $\theta_{\mathrm{s}}$ is the saturated water content and $\alpha$ and $n$ are curve fitting parameters. Values of $\theta_{\mathrm{r}}, \theta_{\mathrm{s}}$ and $n$ are taken from Leij et al. (1996) and $\alpha$ from Ghanbarian-Alavijeh et al. (2010).

\begin{tabular}{llllll}
\hline Depth $(\mathrm{cm})$ & Soil texture & $\theta_{\mathrm{r}}$ & $\theta_{\mathrm{s}}$ & $\alpha$ & $N$ \\
\hline $0-20$ & Silt loam & 0.061 & 0.43 & 0.565 & 1.39 \\
$21-30$ & Silt clay loam & 0.098 & 0.55 & 0.500 & 1.41 \\
$31-50$ & Silt clay & 0.163 & 0.47 & 0.600 & 1.39 \\
\hline
\end{tabular}

spanned $2 \times 0.5 \mathrm{~m}$ whilst the area sampled in the model was $1 \times 0.45 \mathrm{~m}$ for Gerard (1967) and $1 \times 0.3 \mathrm{~m}$ for Knight et al. (1992) (Fig. 6).

At the start of Knight et al.'s (1992) experiment, fresh cow manure $\left(E_{x}=21.2 \mathrm{~kJ} / \mathrm{g}\right.$; Wang et al., 2011) was applied at a rate of $200 \mathrm{~g} / \mathrm{m}^{2}$ and assumed to be mixed into the top $10 \mathrm{~cm}$ of the soil profile (Fig. 6). The timing of manure application is not stated in the study but a sensitivity analysis (Appendix D) showed that the model was only sensitive to the timing of application during unfavourable soil water conditions (June-September) when aestivation is common. Here, we assume a manure application date of 1st April 1990.

Model simulations were initialized with 100 individuals of each life cycle stage (adults, juveniles and cocoons) and run for 50 years to allow the population to stabilise before making observations in the sample area. Major considerations for modelling populations under undisturbed field conditions are seasonal variations in soil temperature and soil water potential and the availability and quality of food resources, outlined in the next sections.

\subsubsection{Soil temperature and soil water potential in the field}

Mean monthly values and standard deviations for soil temperature under grass at 10,20 and $30 \mathrm{~cm}$ and soil water content estimates were obtained from Rothamsted Experimental Station for both field trials simulated. The soil texture was reported as a silty loam with an underlying clay sub-soil, and we have assumed a transition in texture from silty loam to silt clay loam to silty clay, outlined in Fig. 6 . We estimate soil water potential $(\psi)$ from water content measurements $\theta\left(\mathrm{cm}^{3} / \mathrm{cm}^{3}\right)$ using the parametric van Gennuchten (1980) model in the form:

$\psi=\frac{1}{\alpha}\left(\left(\frac{\theta_{\mathrm{s}}-\theta_{\mathrm{r}}}{\theta-\theta_{\mathrm{r}}}\right)^{\frac{n}{n-1}}-1\right) \quad$ (3)where $\psi$ is in units $-\mathrm{kPa}, \theta_{\mathrm{r}}$ and $\theta_{\mathrm{s}}$ are the residual and saturated water contents respectively, and $\alpha$ and $n$ are parameters directly dependent on soil texture. The values of $\theta_{\mathrm{r}}, \theta_{\mathrm{s}}, \alpha$ and $n$ were obtained from the literature for the soil textures in the field trial simulated (Table 4).

Seasonal variations in soil water potential and temperature for the soil depths sampled by Gerard (1967) for 1959 are presented in Fig. 7.

\subsubsection{Soil organic matter in the field}

Soil organic matter represents a key food source for endogeic earthworms like A. caliginosa (e.g. Edwards and Lofty, 1977). In the model, we use soil bulk density as a proxy for food availability and SOM represents the energy content of the food. Although this is a simplification of the diversity of resources available to earthworms, particularly epigeic and anecic species which feed at the soil surface, here we assume these details are sufficient for modelling the feeding behaviour of endogeic species in the soil profile of undisturbed pastures. Knight et al. (1992) recorded soil bulk densities of 0.75 and $1.06 \mathrm{~g} / \mathrm{cm}^{3}$ in the top $10 \mathrm{~cm}$ and deeper layers of the soil profile respectively and we assumed a bulk density of $1.10 \mathrm{~g} / \mathrm{cm}^{3}$ for the soil in Gerard (1967). The feeding dynamics of $A$. caliginosa in pasture were modelled by estimating variations in SOM with season and depth. SOM content generally declines with depth in the soil profile (Lavelle and Spain, 2001).

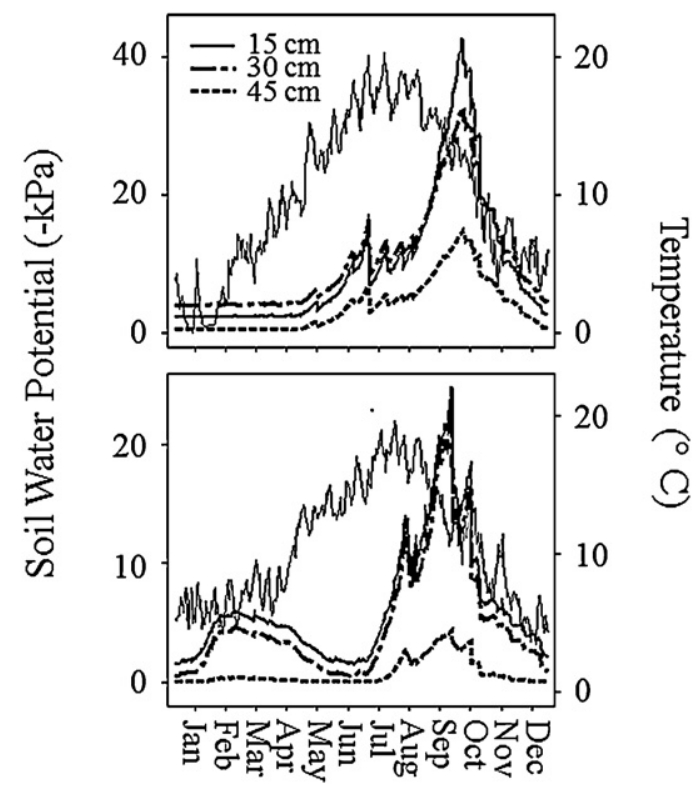

Fig. 7. Seasonal variations in soil water potential (bold lines and left-hand axis: solid, dashed and dotted lines represent mean values at 15,30 and $45 \mathrm{~cm}$ soil depths respectively) with depth and mean soil temperature at $10 \mathrm{~cm}$ (faint solid line and right-hand axis) for (top) Gerard's (1967) and (bottom) Knight et al. (1992). Variations in soil water potential with soil depth result from differences in soil water content $\left(\mathrm{cm}^{3} / \mathrm{cm}^{3}\right)$ and changes in soil texture.

Celik (2005) measured the SOM content of a pasture soil to range from $44.6 \mathrm{~g} / \mathrm{kg}$ in the top $10 \mathrm{~cm}$ to $37.9 \mathrm{~g} / \mathrm{kg}$ at a depth of $10-20 \mathrm{~cm}$. The soil carbon stock of a silty loam soil was measured by Balesdent et al. (2000) as $1.53,1.34$ and $1.09 \mathrm{~kg} / \mathrm{m}^{2}$ at depths of 10 , 20 and $30 \mathrm{~cm}$ respectively, which is in line with observations made by Jenkinson (1969) at Rothamsted. From these values and considering carbon to account for 58\% of SOM (Guo and Gifford, 2002), we assumed a maximum SOM content of $6 \%$ for the top $30 \mathrm{~cm}$ of the soil profile. Our estimate is in agreement with observations from Rothamsted in the range 5-7.1\% SOM (Coleman et al., 1997; Harrod and Hogan, 2008).

Although no clear seasonal variations in SOM content have been identified, some general patterns are evident in the literature for field soils (e.g. not sieved of macro-organic material). For example, McNaughton et al. (1998) found root biomass in undisturbed grasslands to peak in summer and decline in winter with a difference of around $300 \mathrm{~g} / \mathrm{m}^{2}$, whilst levels are similar during spring and autumn. Bardgett et al. (1997) recorded similar patterns for microbial biomass in grassland, with differences between summer and winter of $200 \mathrm{~g} / \mathrm{cm}^{2}$. We used these general observations to model seasonal variations in SOM as shown in Fig. 8. Daily variations in SOM, from plant, root and microbial growth and death were modelled by assigning each patch daily energy contents $(\mathrm{kJ} / \mathrm{g})$, taken at random from normal distributions as in Fig. 8. This also produced spatial heterogeneity in soil profiles.

\subsection{Goodness of fit of model outputs to recorded data}

We used the coefficient of determination $\left(R^{2}\right)$ to evaluate how well the model's outputs fit the observed data. $R^{2}$ is defined as $1-$ ((residual sum of squares)/(total sum of squares)), with values closer to 1 representing better agreement between observed and predicted values. Note the value of $R^{2}$ can be negative if the fit is poor. Conventional statistical methods of assessing the $R^{2}$ values are not applicable here because the parameter values are not 


\section{Soil Organic Matter (\%)}

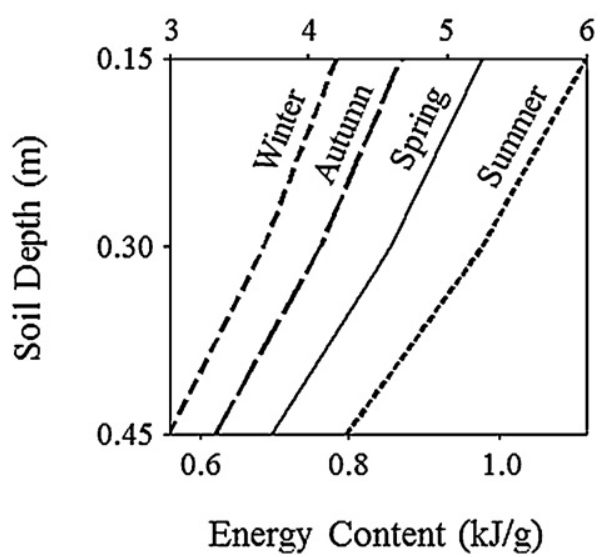

Fig. 8. Estimates of soil organic matter (\%) and equivalent energy contents (kJ/ $\mathrm{g}$ soil) in relation to depth and season for a pasture soil used to simulate the field conditions of Gerard (1967) and Knight et al. (1992). Lines represent the mean and SD is taken as $10 \%$.

estimated from the data. However, we suggest that values of $R^{2}>0.5$ can generally be taken to indicate a good fit.

\section{Results}

Mechanistic models for potential use in practical applications should be evaluated to ensure that they provide an adequate representation of the real system. Here, we evaluate our model's prediction against multiple independent records of $A$. caliginosa life cycle processes in the laboratory and population dynamics in the field.

\subsection{Individual life cycle processes}

Life cycle data for $A$. caliginosa from experimental studies are presented together with outputs of model simulations run under the same conditions (Table 3). Fig. 9(a) and (b) show individual changes in body mass under food conditions relevant to field populations when the earthworms are fed with plant material. Fig. 9(c) and (d) show increased growth rates when individuals were fed more energy rich resources such as manure, underlining the direct link between energy assimilation and expenditure to life cycle processes. The model outputs fit the data well as shown by the $R^{2}$ values in Fig. 9.

Boström (1988) recorded growth and cocoon production of five adult $A$. caliginosa maintained for 28 days on meadow fescue, lucerne or barley (Fig. 10). Model outputs again fit well with the recorded data.

Cumulative cocoon production of $A$. caliginosa provided with manure and meadow fescue as food was recorded by Lofs-Holmin (1983) and Boström and Lofs-Holmin (1996); respectively. There is good model agreement with the data for variation of cocoon production with temperature (Fig. $11 \mathrm{~b}: R^{2}=0.92$ ) and the data for cocoon production do not differ significantly from the model outputs ( $t$ test, $p>0.05$ ).

\subsection{Field populations}

The vertical distribution of an A. caliginosa population reported by Gerard (1967) is compared to model simulation results in Fig. 12. In September, Gerard (1967) did not find any individuals but suggested that the whole population was present below the soil depth sampled in the experiment $(45 \mathrm{~cm})$. In the model, those individuals not aestivating were present below $31 \mathrm{~cm}$. Model outputs fit well with the recorded data at both soil depths.

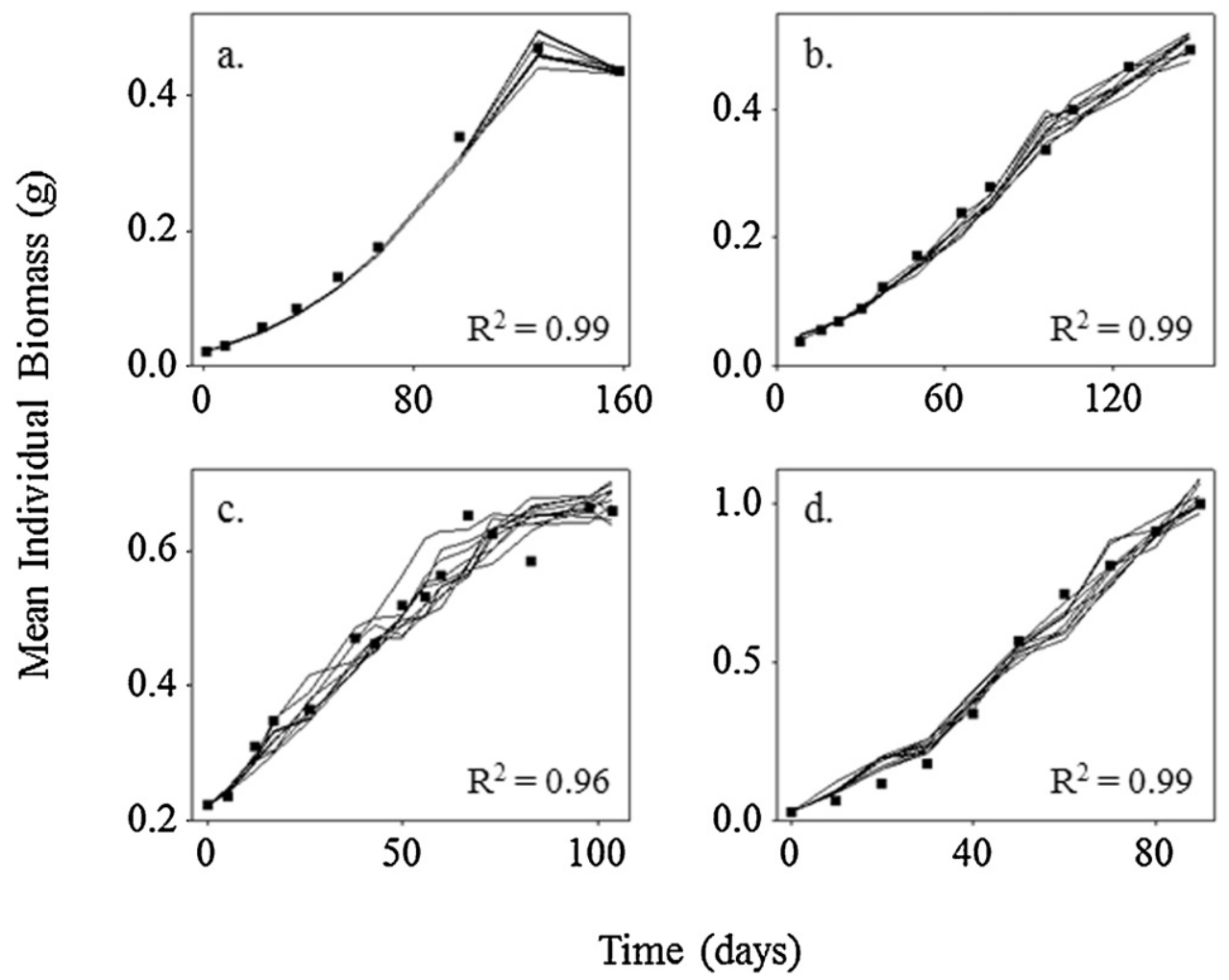

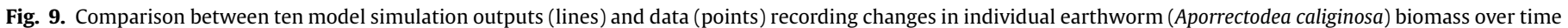

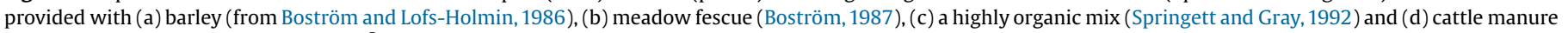
(Lofs-Holmin, 1983) for food. Average $R^{2}$ values are shown in the bottom right of each panel. 

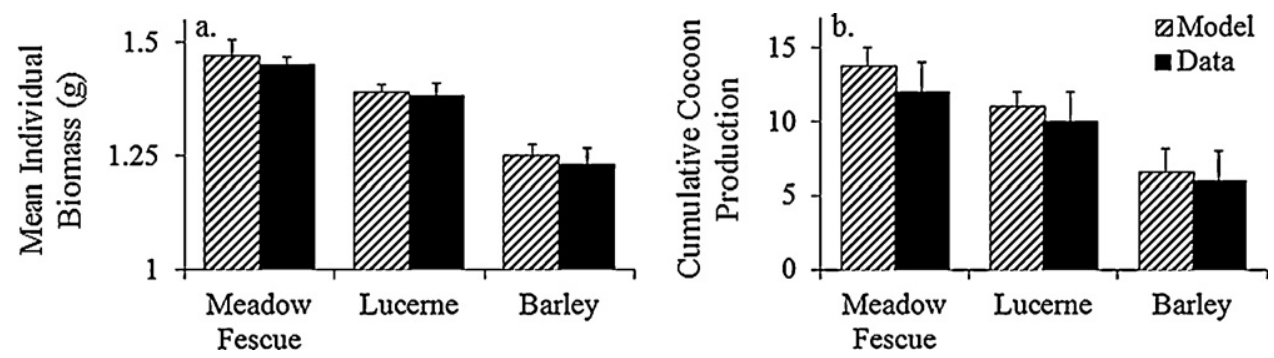

Fig. 10. Comparison between model outputs (hatched bars, mean + SE from 10 simulations) and recorded data from Boström (1988) (solid bars) for (a) individual biomass and (b) cocoon production of groups of five adult earthworms (Aporrectodea caliginosa) maintained on the indicated plant foods. Average $R^{2}$ values are (a) 0.96 and (b) 0.75 .
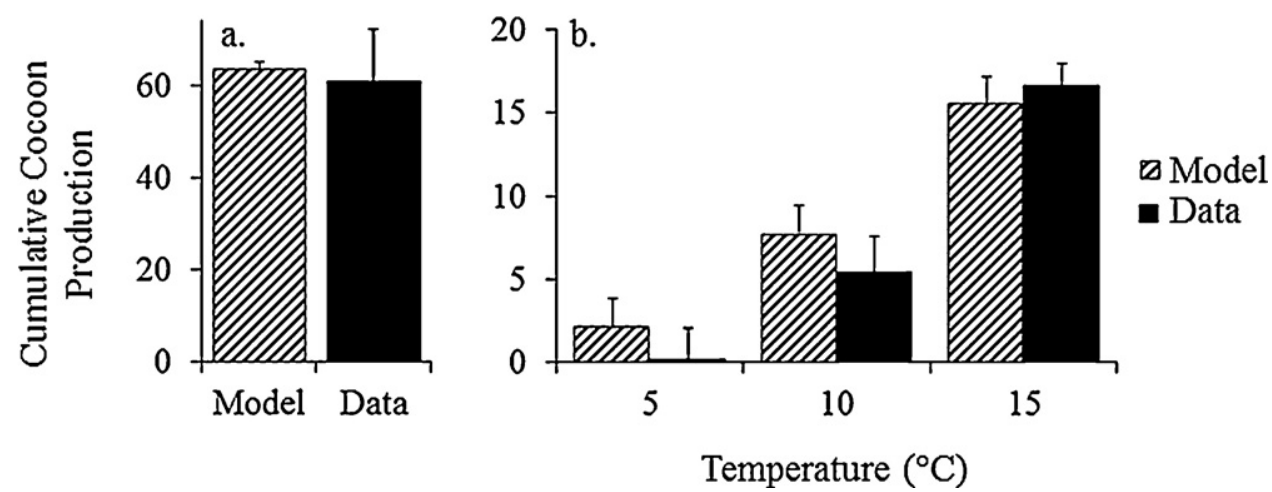

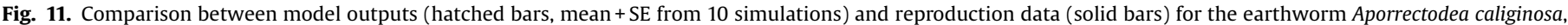

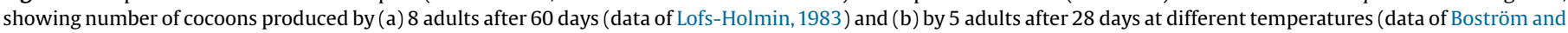
Lofs-Holmin, 1996).

The population densities of adults, juveniles and cocoons were recorded each month for the sampled year in Gerard (1967). Data from Gerard (1967) are presented alongside model outputs in Fig. 13. Although the model predicts seasonal patterns of juvenile density reasonably well (Fig. 13 (b), $R^{2}=0.70$ ), the fits for adult densities and cocoons are poor (Figs. 13(a) and (c), $R^{2}=0.06$ and -0.08 respectively). However, the pattern of modelled adult densities replicates that of the data, with a maximum in spring, and a minimum in September (Fig. 13(a)) due to dry soil conditions driving the population to soil depths below the sampled area (see above). The observed cocoon densities from January to June $\left(453 \pm 216 / \mathrm{m}^{2}\right)$ are higher than predicted $\left(131 \pm 57 / \mathrm{m}^{2}\right)$ during half of the year (Fig. 13(c)). However, the observed densities are much higher than those recorded by Boström and Lofs-Holmin (1996) in a meadow fescue lay, with a measured maximum density of 176 cocoons $/ \mathrm{m}^{2}$ in June.

Earthworm population biomasses reported by Knight et al. (1992) under field conditions are compared with model simulation

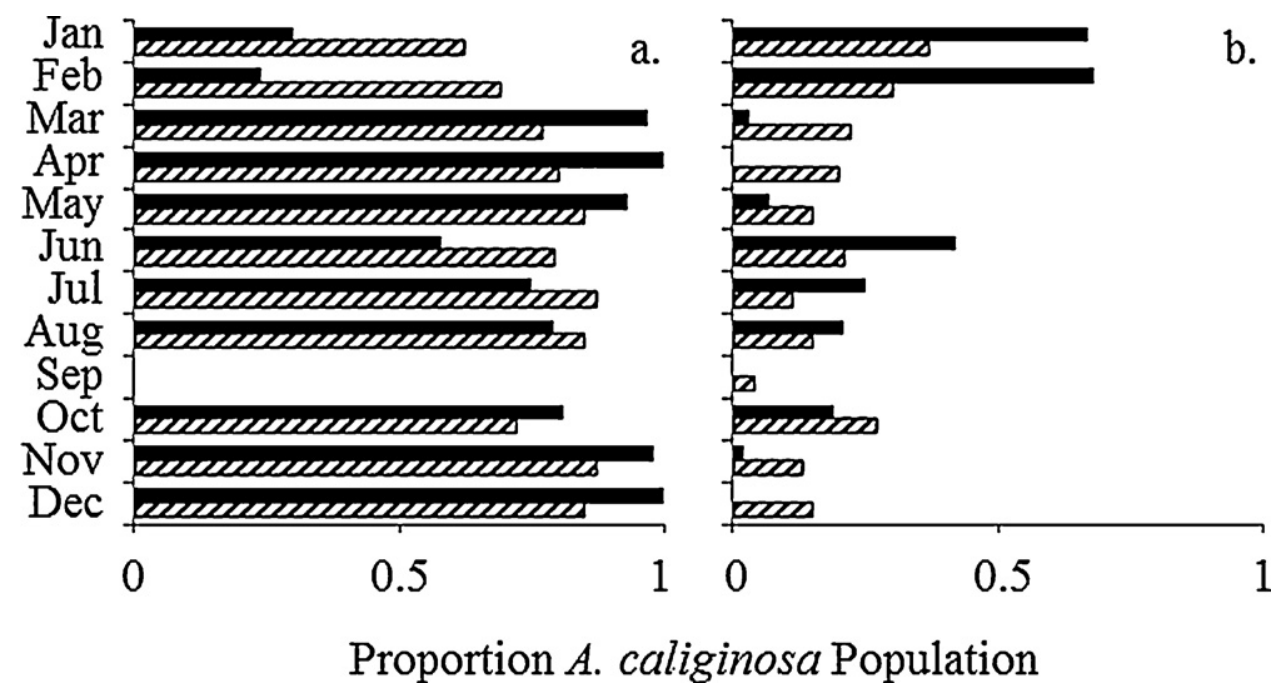

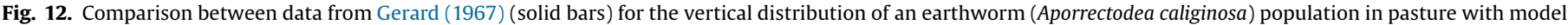

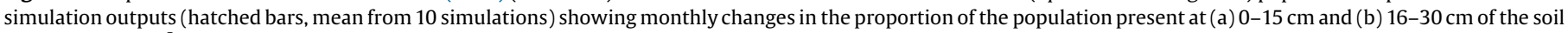
profile. Average $R^{2}$ values are (a) 0.87 and (b) 0.80 . 


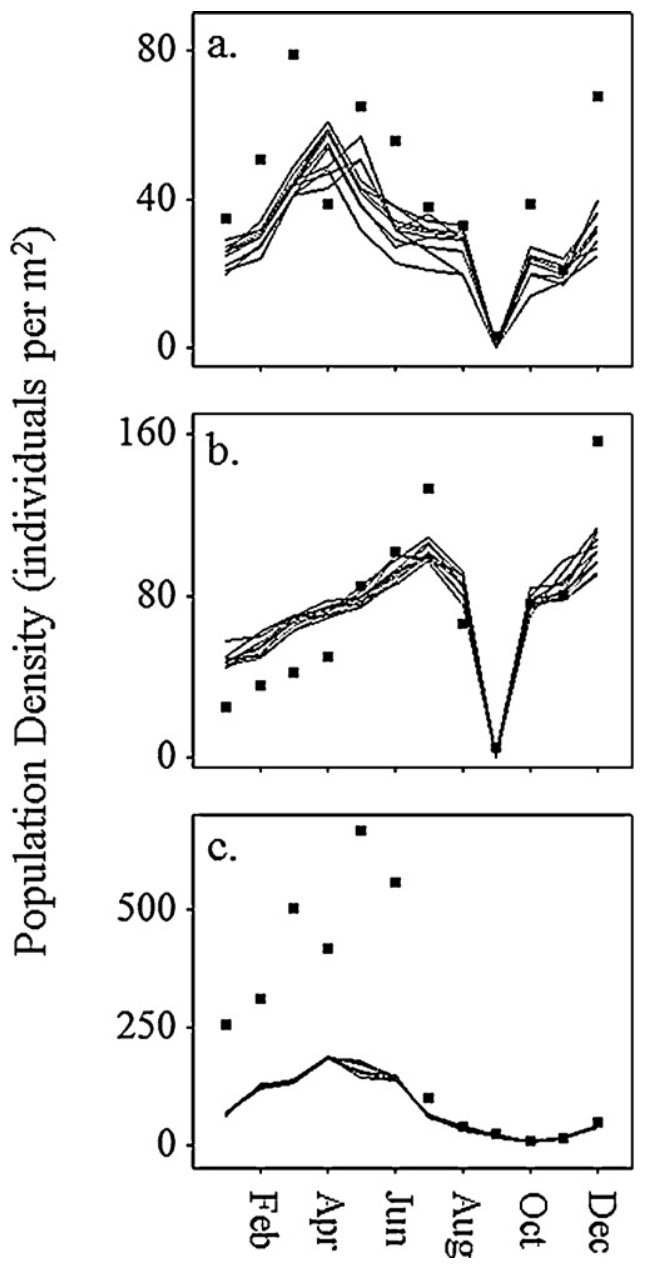

Fig. 13. Comparison of earthworm (Aporrectodea caliginosa) population density data from Gerard (1967) (symbols) and model outputs (lines, mean from 10 simulations) for (a) adults, (b) juveniles and (c) cocoons for the year 1959 in pasture at Rothamsted, UK. Average $R^{2}$ values are (a) 0.06 , (b) 0.70 and (c) -0.08 . results for $A$. caliginosa in Fig. 14. Under control conditions (Fig. 14(a)) there is no consistent variation with time, but under experimental conditions, population biomass increases for 9 weeks after deposition of an artificial cow pat (Fig. 14(b)). The field data are higher than the model output under both conditions. However, A. caliginosa only comprised on average $44.5 \%$ of the total population, and when this is taken into account agreement is better (Fig. 14(c) and (d)).

Knight et al. (1992) recorded an earthworm density of $354 \pm 73$ individuals $/ \mathrm{m}^{2}$ in pasture. Considering $A$. caliginosa to comprise $44.5 \%$ gives a population density and biomass of $158 \pm 33$ individuals $/ \mathrm{m}^{2}$ and $20.6 \mathrm{~g} / \mathrm{m}^{2}$. Model simulations recorded a mean population density and biomass of $147 \pm 23$ individuals $/ \mathrm{m}^{2}$ and $20.9 \pm 4.1 \mathrm{~g} / \mathrm{m}^{2}( \pm \mathrm{SE}, N=4)$, closely matching the observations of Knight et al. (1992).

\subsubsection{Sensitivity analysis}

The implications for modelling movement as a trade-off between soil water potential and food quality, as in Fig. 5, were evaluated by comparing model outputs when the movement is assumed to be random for the Knight et al. (1992) manure experiment. Fig. 15 shows how important capturing directional movement is for predicting the dynamics of earthworm populations following land management scenarios.

Model outputs are sensitive to the SOM content of the soil as shown in Fig. 16. Earthworm density and biomass change linearly by $14 \%$ for each $10 \%$ change in SOM content in the modelled Knight et al. (1992) pasture trial.

\section{Discussion}

Our model fits well the records of individual cocoon production and growth of body mass in A. caliginosa for all the experimental studies we know of. It is the first published model to consider temperature, soil moisture and resources, which are fundamental ecological drivers for understanding earthworm populations (Schneider and Schröder, 2012). Simulated laboratory studies varied in the foods provided (Figs. 9-11) and were carried out at several different temperatures (Fig. 11(b)). The ability of the model

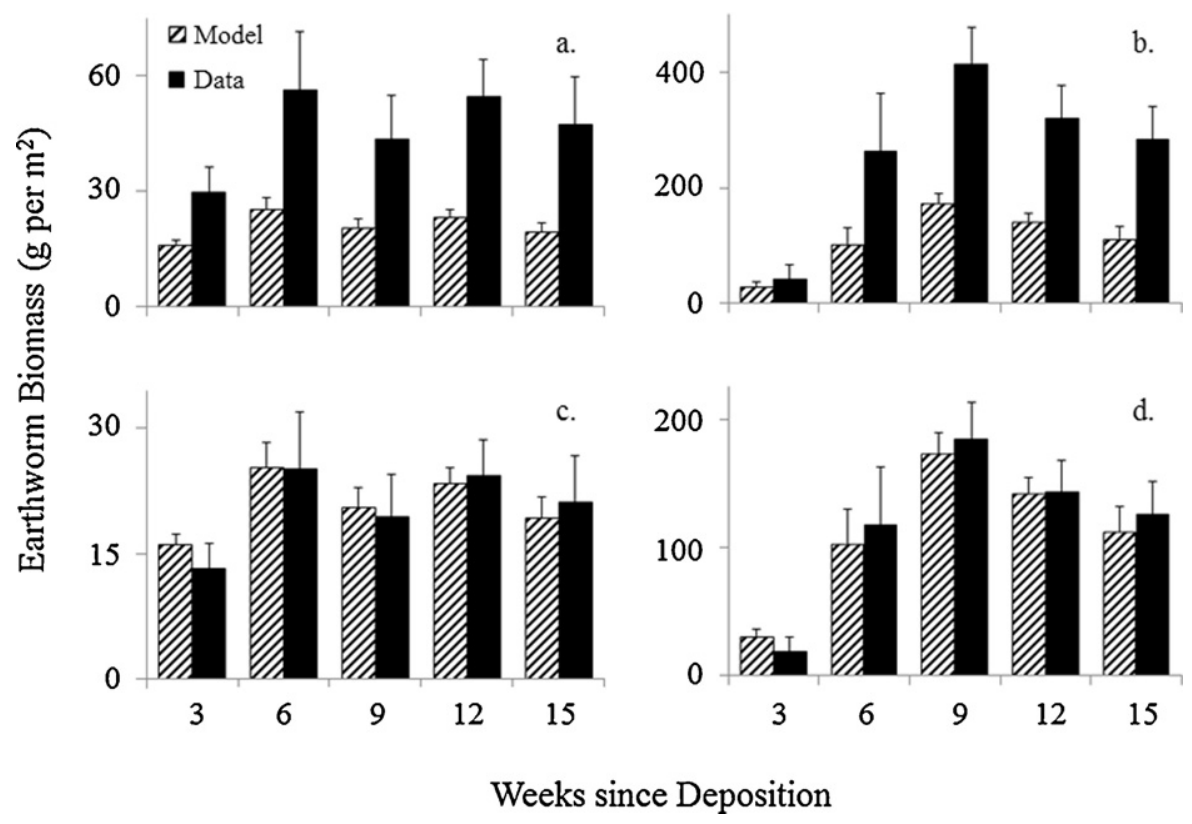

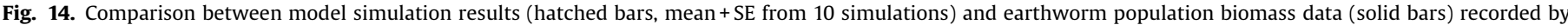

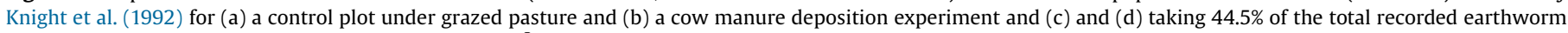
biomass to represent Aporrectodea caliginosa. Average $R^{2}$ values are (a) -6.47 , (b) -0.91 , (c) 0.85 and (d) 0.96 . 


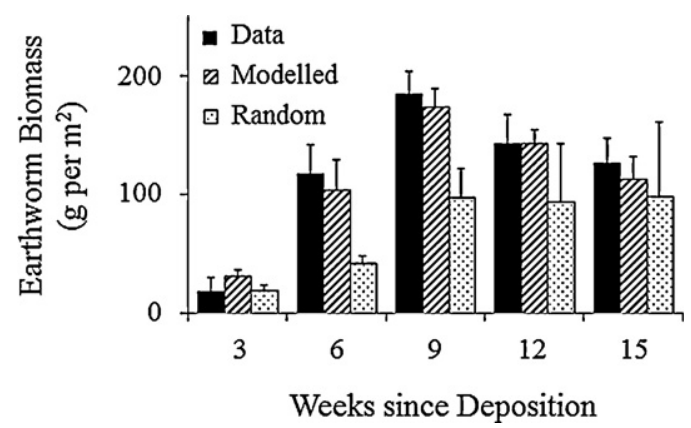

Fig. 15. Comparison between data from Knight et al. (1992); representing only Aporrectodea caliginosa ( $44.5 \%$ of the total population), for a cow manure deposition experiment (solid bars) and model simulation results when individual movement depends on soil water and food quality conditions (hatched bars: $R^{2}=0.96$ ) and when movement is random (dotted bars: $R^{2}=-0.11$ ).

to adequately reproduce individual life history traits over a range of controlled conditions in the laboratory, supports our representation of individual physiology through energy budgets. In field trials, the model predicts the spatiotemporal distribution of $A$. caliginosa populations in the soil profile (Fig. 12), alongside seasonal patterns in the population stage-structure (Fig. 13). The model's ability to reproduce the patterns observed in Knight et al. (1992) (Fig. 14) illustrates how energy budget IBMs can be used to make reliable predictions of population-level exposure and responses to changing soil conditions, and thereby support informed land management decisions.

Variations in soil physio-chemical properties are known to alter the distribution and abundance of earthworms through the soil profile (Jiménez and Decaëns, 2000). Here, synthesis of knowledge on the effects of food availability and soil water potential on individual A. caliginosa movement account, to a large extent, for the vertical distribution of field populations in pasture (Fig. 12). In Gerard's (1967) field trial the effects of soil water potential on $A$. caliginosa movement are predominant in September (Figs. 7 and 12 ), when individuals move to deeper soil layers to avoid dry soil conditions. The models ability to replicate these patterns support its application to predict how environmental conditions at the soil surface affect the population's structure. However, modelling involves a trade-off between structural realism and complexity, and so when factors not captured here (e.g. pH, chemical applications, and compaction) are important in understanding

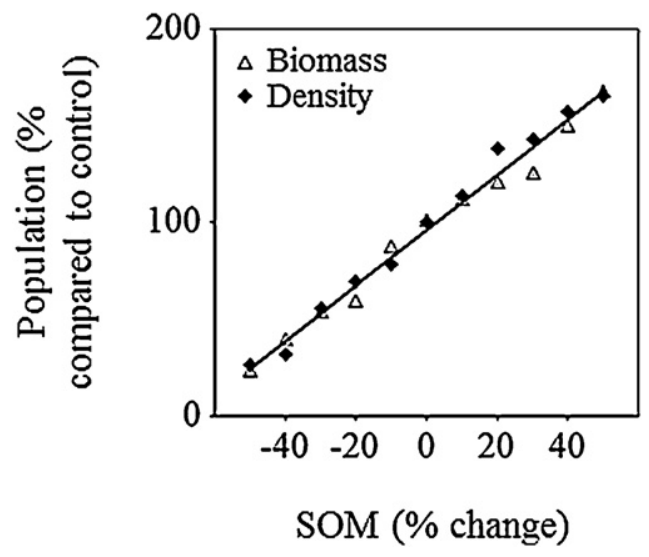

Fig. 16. Modelled responses of earthworm (Aporrectodea caliginosa) population biomass and density to $10 \%$ increments in SOM content of the pasture plot sampled by Knight et al. (1992) at 15 weeks, presented as a percentage change compared to the control population. earthworm population dynamics, subsequent model development will be required.

The abundance of earthworms in pasture is closely related to organic matter inputs (e.g. Edwards and Bohlen, 1996; El-Duweini and Ghabbour, 1965). Hence, predicting realistic earthworm population dynamics in the field is dependent on accurate estimates of SOM (Fig. 16). Fraser et al. (1996) found earthworm populations to decline with time under arable cultivation and increase with time under pasture production in New Zealand, due to changes in the SOM content. A maximum population density and biomass of 950 individuals $/ \mathrm{m}^{2}$ and $185.7 \mathrm{~g} / \mathrm{m}^{2}$ were reported in plots used as pasture for 6-9 years. A relatively low SOM content of $3 \%$, in comparison to the average 6\% assumed for the Knight et al. (1992) field trial, was recorded. The high earthworm population abundances reported are likely due to a higher soil bulk density of $1.4 \mathrm{~g} / \mathrm{cm}^{3}$, which determines the amount of soil available as food. When our model is set up as in the simulation of Knight et al. (1992) but with a soil density of $1.4 \mathrm{~g} / \mathrm{cm}^{3}$ and SOM content of $3 \%$, rather than $0.75-1.06 \mathrm{~g} / \mathrm{cm}^{3}$ and $6 \%$, an average $A$. caliginosa population density and biomass of $636 \pm 60$ individuals $/ \mathrm{m}^{2}$ and $130 \pm 13 \mathrm{~g} / \mathrm{m}^{2}$ were recorded respectively, which closely agrees with Fraser et al. (1996)'s observations. This suggests that the use of soil bulk density and SOM are useful proxies for food availability and quality for predicting earthworm population dynamics.

Many authors have reported the beneficial effects of animal waste applications to field populations of earthworms. Satchell (1955) reported a three-fold increase in earthworm population density when manure was applied to grassland, whilst Edwards and Lofty (1977) found manure applications to arable land resulted in earthworm abundances 14 times those of unmanipulated plots. At the individual level Barley (1959) found the provision of sheep manure at the soil surface increased $A$. caliginosa body weight by $111 \%$ after 40 days. The effects of providing individual $A$. caliginosa with high quality foods, such as manure, on their life cycle processes can be seen in our simulations of the laboratory experiments of Lofs-Holmin (1983) in Fig. 9(d) and Fig. 11(a). Comparing these growth and reproduction rates to those recorded when individuals were provided with plant material and soil mixtures (e.g. Fig. 9(a) and (b) and Fig. 10), highlights the direct link between the energy content of food and individual physiology.

Field population results in Fig. 14(b) and (d) clearly show how the quality of food resources affects population dynamics. The assumptions made about individual behaviour in the field, particularly movement, were essential to achieving good model fits to population data. Comparisons between model outputs for the cow manure experiment when movement was explicitly modelled as in Fig. 5, and when movement was assumed to be random in Fig. 15 suggest that the model adequately captures the factors driving the spatial distribution of earthworms. Furthermore, sensitivity analysis of SOM effects on the abundance of earthworm populations (Fig. 16) is in close agreement with observations by Hendrix et al. (1992); who found soil organic carbon (\%) to describe earthworm abundance in conventional and no-tillage agroecosystems alongside grass meadows.

Earthworms are important soil engineers and so the ability to predict their abundance has wide application in ecology, conservation and land management. Our mechanistic model is able to predict the abundance and distribution of the dominant earthworm species in agro-ecosystems, A. caliginosa, in spatially heterogeneous soil profiles of undisturbed habitats. We hope the model will find many applications because of the vital role earthworms play in agricultural habitats (Hendrix and Edwards, 2004). For instance, earthworms are focal organisms for environmental risk assessment of pesticides in Europe (under Regulation (EC) No 1107/2009; see SANCO, 2002), and our model can help assess the population consequences of pesticides application 
following inclusion of a toxicological submodel (e.g. Johnston et al., 2014). The spatial distribution of individuals in field populations is predicted by the model and so, if the fate of applied chemicals is known, then the exposure of individuals to pesticides can be calculated. For application to anecic earthworm species such as Lumbricus terrestris, additional model development may be required to capture more spatially explicit movement and feeding behaviour. Furthermore the model could be used to investigate population level effects of multiple stressors (e.g. tillage and pesticide applications), or variation of pesticide application timings, or climatic conditions. Considerations for modelling tillage in agroecosystems include mortality, redistribution of soil organic matter and the effects of compaction on the energy budgets and movement of individuals in the soil profile (e.g. Kretzschmar, 1990). For more widespread application, the model should also be tested in a variety of climatic conditions. The authors are currently working on applying the presented model to investigate the interactions between variable chemical, mechanical and environmental conditions. Also important is the ability to predict the local food supplies of animals that eat earthworms, including species of potential conservation concern such as wading birds (e.g. the lapwing Vanellus vanellus), and species sometimes regarded as pests such as flatworms (Bipalium adventitium) and foxes (Vulpes vulpes).

\section{Acknowledgements}

We thank Anne Verhoef for assistance modelling soil water potential and Rothamsted Research for supplying weather input data. This research has been financially supported by BBSRC studentship BB/1532429/1, with CASE support from Syngenta.

\section{Appendix A. Supplementary data}

Supplementary data associated with this article can be found, in the online version, at http://dx.doi.org/10.1016/j.apsoil.2014.06.001.

\section{References}

Balesdent, J., Chenu, C., Balabane, M., 2000. Relationship of soil organic matter dynamics to physical protection and tillage. Soil Till. Res. 53, 215-230.

Bardgett, R.D., Leemans, D.K., Cook, R., Hobbs, P.J., 1997. Seasonality of the soil biota of grazed and ungrazed hill grasslands. Soil Biol. Biochem. 29, 1285-1294.

Barley, K.P., 1959. The influence of earthworms on soil fertility. II. Consuption of soil and organic matter by the earthworm Allolobophora caliginosa (Savigny). Aust. J. Agric. Res 10, 179-185.

Bayley, M., Overgaard, J., Høj, A.S., Malmendal, A., Nielsen, N.C., Holmstrup, M., Wang, T., 2010. Metabolic changes during estivation in the common earthworm Aporrectodea caliginosa. Physiol. Biochem.Zool. 83, 541-550.

Blakemore, R., 2002. Cosmopolitan Earthworms: An Eco-taxonomic Guide to the Peregrine Species of the World. VermEcology, Australia.

Blouin, M., Hodson, M.E., Delgado, E.A., Baker, G., Brussard, L., Butt, K.R., Dai, J. Dendooven, L., Peres, G., Tondoh, J.E., Cluzeau, D., Brun, J.-J., 2013. A review of earthworm impact on soil function and ecosystem services. Eur. J. Soil Sci. 64, $161-182$.

Boström, U., 1987. Growth of earthworms (Allolobophora caliginosa) in soil mixed with either barley, lucerne or meadow fescue at various stages of decomposition. Pedobiologia 30, 311-321.

Boström, U., 1988. Growth and cocoon production by the earthworm Aporrectodea caliginosa in soil mixed with various plant materials. Pedobiologia 32, 77-80.

Boström, U., Lofs-Holmin, A., 1986. Growth of earthworms (Allolobophora caliginosa) fed shoots and roots of barley, meadow fescue and lucerne: studies in relation to particle size, protein, crude fiber content and toxicity. Pedobiologia 29, 1-12.

Boström, U., Lofs-Holmin, A., 1996. Annual population dynamics of earthworms and cocoon production by Aporrectodea caliginosa in a meadow fescue ley. Pedobiologia 40, 32-42.

Butenschoen, O., Marhan, S., Langel, R., Scheu, S., 2009. Carbon and nitrogen mobilisation by earthworms of different functional groups as affected by soil sand content. Pedobiologia 52, 263-272.

Celik, I., 2005. Land-use effects on organic matter and physical properties of soil in a southern Mediterranean highland of Turkey. Soil Till. Res. 83, 270-277.
Curry, J.P., 2004. Factors affecting the abundance of earthworms in soils. In: Edwards, C. A. (Ed.), Earthworm Ecology. CRC press, LLC, Boca Raton, FL, pp. 91-114.

DeAngelis, D.L., Mooij, W.M., 2005. Individual-based modelling of ecological and evolutionary processes. Annu. Rev. Ecol. Evol. Syst. 36, 147-168.

Doube, B., Styan, C., 1996. The response of Aporrectodea rosea and Aporrectodea trapezoides (Oligochaeta: Lumbricidae) to moisture gradients in three soil types in the laboratory. Biol. Fert. Soils 23, 166-172.

Edwards, C.A., Bohlen, P.J., 1996. Biology and Ecology of Earthworms, third ed. Chapman and Hall, London.

Edwards, C.A., Lofty, R., 1977. The Biology of Earthworms, second ed. Chapman and Hall, London.

El-Duweini, A.K., Ghabbour, S.I., 1965. Population density and biomass of earthworms in different types of Egyptian soils. J. Appl. Ecol. 2, 271-287.

Evans, M.R., Grimm, V., Johst, K., Knuuttila, T., de Langhe, R., Lessells, C.M., Merz, M., O'Malley, M.A., Orzack, S.H., Weisberg, M., Wilkinson, D.J., Wolkenhauer, O., Benton, T.G., 2013. Do simple models lead to generality in ecology? Trends Ecol. Evol. 28, 578-583.

Eriksen-Hamel, N.S., Whalen, J.K., 2006. Growth rates of Aporrectodea caliginosa (Oligochaetae: Lumbricidae) as influenced by soil temperature and moisture in disturbed and undisturbed soil columns. Pedobiologia 50, 207-215.

Feller, C., Brown, G.C., Blanchart, E., Deleporte, P., Chernyanskii, S.S., 2003. Charles Darwin, earthworms and the natural sciences: various lessons from past to future. Agr. Ecosyst. Environ. 99, 29-49.

Forbes, J.C., Watson, R.D., 1992. Plants in Agriculture. Cambridge University Press, Cambridge, pp. 303.

Fraser, P.M., Williams, P.H., Haynes, R.J., 1996. Earthworm species, population size and biomass under different cropping systems across the Canterbury Plains, New Zealand. Appl. Soil Ecol. 3, 49-57.

Gerard, B.M.,1967. Factors affecting earthworms in pastures. J. Anim. Ecol. 36, 235-252.

Ghanbarian-Alavijeh, B., Liaghat, A., Guan-Hua, H., Van Genuchten, M. Th., 2010. Estimation of the van Genuchten soil water retention properties from soil textural data. Pedosphere 20, 456-465.

Granval, P., Aliaga, R., 1988. Analyse critique des connaissances sur le predateurs de lombriciens. Gibier Faune Sauvage 5, 71-94.

Grimm, V., Revilla, E., Berger, U., Jeltsch, F., Mooij, W.M., Railsback, S.F., Thulke, H., Weiner, J., Wiegand, T., DeAngelis, D.L., 2005. Pattern-oriented modeling of agent-based complex systems: lessons from ecology. Science 310, 987-991.

Grimm, V., Berger, U., DeAngelis, D.L., Polhill, J.G., Giske, J., Railsback, S.F., 2010. The ODD protocol: a review and first update. Ecol. Model. 221, 2760-2768.

Grimm, V., Railsback, S.F., 2012. Agent-Based and Individual-Based Modeling: A Practical Introduction. Princeton University Press, Princeton, NJ.

Gunadi, B., Blount, C., Edwards, C.A., 2002. The growth and fecundity of Eisenia fetida (Savigny) in cattle solids pre-composted for different periods. Pedobiologia 46 15-23.

Guo, L.B., Gifford, R.M., 2002. Soil carbon stocks and land use change: a meta analysis. Global Change Biol. 8, 345-360.

Harrod T.R., Hogan D.V., 2008. The soils of North Wyke and Rowden. Revised edition of Harrod T.R. (1981) Soils in Devon IV: Sheet SS61 (Chulmleigh). Soil Survey Rec No 70. http://www.rothamsted.ac.uk/sites/default/files/SoilsNWRowden.pdf

Hendrix, P.F., Mueller, B.R., Bruce, R.R., Langdale, G.W., Parmelee, R.W., 1992 Abundance and distribution of earthworms in relation to landscape factors in Georgia Piedmont, U.S.A. Soil Biol. Biochem. 24, 1357-1361.

Hendrix, P.F., Edwards, C.A., 2004. Earthworms in agroecosystems: research approaches, In: Edwards, C.A. (Ed.), Earthworm Ecology. second ed. St. Lucie Press, Boca Raton, pp. 287-295.

Hobbelen, P.H.F., van Gestel, C.A.M., 2007. Using dynamic energy budget modeling to predict the influence of temperature and food density on the effect of $\mathrm{Cu}$ on earthworm mediated litter consumption. Ecol. Model. 202, 373-384.

Holmstrup, M., Østergaard, I.K., Nielsen, A., Hansen, B., 1991. The relationship between temperature and cocoon incubation time for some Lumbricid earthworm species. Pedobiologia 35, 179-184.

Holmstrup, M., 2001. Sensitivity of life history parameters in the earthworm Aporrectodea caliginosa to small changes in soil water potential. Soil. Biol. Biochem. 33, 1217-1223.

Jager, T., Reinecke, S.A., Reinecke, A.J., 2006. Using process-based modelling to analyse earthworm life cycles. Soil. Biol. Biochem. 38, 1-6.

Jégou, D., Cluzeau, D., Wolf, H.J., Gandon, Y., Tréhen, P., 1998. Assessment of the burrow systems of Lumbricus terrestris, Aporrectodea giardia, and Aporrectodea caliginosa using X-ray computed tomography. Biol. Fert. Soils 26, 116-121.

Jenkinson D.S., 1969. Radiocarbon dating of soil organic matter. Rep. Rothamsted Exp. Stn. For 1968. Pt. 2:103-109.

Jiménez, J.J., Decaëns, T., 2000. Vertical distribution of earthworms in grassland soils of the Colombian Llanos. Biol. Fert. Soils 32, 463-473.

Johnston, A.S.A., Hodson, M.E., Thorbek, P., Alvarez, T., Sibly, R.M., 2014. An energy budget agent-based model of earthworm populations and its application to study the effect of pesticides. Ecol. Model. 280, 5-17.

Keith, A.M., Robinson, D.A., 2012. Earthworms as natural capital: ecosystem service providers in agricultural soils. Economology J. 11, 91-99.

Knight, D., Ellio, W., Anderson, J.M., Scholefield, D., 1992. The role of earthworms in managed permenant pastures in Devon, England. Soil Biol. Biochem. 24,1511-1517.

Kretzschmar, A., 1990. Burrowing ability of the earthworm Aporrectodea longa limited by soil compaction and water potential. Biol. Fert. Soils 11, 48-51.

Lavelle, P., Spain, A.V., 2001. Soil Ecology. Kulwer Academic Publishers, The Netherlands. 
Le Bayon, R.C., Moreau, S., Gascuel-Odoux, C., Binet, F., 2002. Annual variations in earthworm surface-casting activity and soil transport by water runoff under a temperate maize agroecosytem. Geoderma 106, 121-135.

Leij, F.J., Alves, W.J., van Genuchten, M.Th., Williams, R., 1996. The UNSODA unsaturated hydraulic database. EPA/600/R-96095. U.S. Environmental Protection Agency, Cincinnati, $\mathrm{OH}$.

Lee, K.E., 1985. Earthworms: Their Ecology and Relationship with Soils and Land Use. Academic Press, Sydney.

Lofs-Holmin, A., 1983. Reproduction and growth of common arable land and pasture species of earthworms (Lumbricidae) in laboratory cultures. Swedish J. Agr Res. 13, 31-37.

Loustau D., 1984. Morphologie et fonctionnement biodynamique de quelques humus hydromophes de l'est de la France, Thèse de $3^{\mathrm{e}}$ Cycle, Université Nancy I. (In: Lavelle, P., Spain, A.V. (Eds.), Soil Ecology, 2001, Kulwer Academic Publishers, The Netherlands) Table 1.8, p. 37.

Lowe, C.N., Butt, K.R., 2003. Influence of food particle size on inter- and intra-specific interactions of Allolobophora chlorotica (Savigny) and Lumbricus terrestris. Pedobiologia 47, 574-577.

McNaughton, S.J., Banyikwa, F.F., McNaughton, M.M., 1998. Root biomass an productivity in a grazing ecosystem: the Serengeti. Ecology 79, 587-592.

Meehan, T.D., 2006. Mass and temperature dependence of metabolic rate in litte and soil invertebrates. Physiol. Biochem. Zool. 79, 878-884.

Paoletti, M.G., 1999. The role of earthworms for assessments of sustainability and as bioindicators. Agr. Ecosyst. Environ. 74, 137-155.

Pedersen, M.B., Bjerre, A., 1991. The relationship between mass of newly hatched individuals and cocoon mass in lumbricid earthworms. Pedobiologia 35, 35-39.

Perez-Losada, M., Ricoy, M., Marshall, J.C., Dominguez, J., 2009. Phylogenetic assessment of the earthworm Aporrectodea caliginosa species complex (Oligochaeta: Lumbricidae) based on mitochondrial and nuclear DNA sequences. Mol. Phylogenet. Evol. 52, 293-302.

Peters, R.H., 1983. The Ecological Implications of Body Size. Cambridge University Press, Cambridge.

Riley, H., Pommeresche, R., Eltun, R., Hansen, S., Korsaeth, A., 2008. Soil structure organic matter and earthworm activity in a comparison of cropping systems with contrasting tillage, rotations, fertilizer levels and manure use. Agr. Ecosyst. Environ. 124, 275-284.
SANCO. 2002. Guidance Document on Terrestrial Ecotoxicology under Council Directive 91/414/EEC. Santé des Consommateurs. European Commission, Health and Consumer Protection Directorate-General, SANCO/10329/2002 rev 2 (final). Brussels, Belgium. Available at: http://ec.europa.eu/food/plant/ protection/evaluation/guidance/wrkdoc09_en.pdf.

Satchell, J.E., 1955. Some aspects of earthworm ecology. In: Kevan, D.M. (Ed.), Soil Zoology. Butterworths, London, pp. 180-203.

Schneider, A.-K., Schröder, B., 2012. Perspectives in modelling earthworm dynamics and their feedbacks with abiotic soil properties. Appl. Soil Ecol. 58, 29-36.

Sibly, R.M., Calow, P., 1986. Physiological Ecology of Animals. Blackwell Scientific Publications, Oxford.

Sibly, R.M., Grimm, V., Martin, B.T., Johnston, A.S.A., Kułakowska, K., Topping, C.J., Calow, P., Nabe-Nielsen, J., Thorbek, P., DeAngelis, D.L., 2013. Representing the acquisition and use of energy by individuals in agent-based models of animal populations. Methods Ecol. Evol. 4, 151-161.

Sinclair, A.R.E., 1989. Population regulation in animals. In: Cherrett, J.M. (Ed.), Ecological Concepts. Blackwell Scientific Publications, Oxford, pp. 197-241.

Springett, J.A., Gray, R.A.J., 1992. Effect of repeated low doses of biocides on the earthworm Aporrectodea caliginosa in laboratory culture. Soil. Biol. Biochem. 24, 1739-1744.

Spurgeon, D.J., Svendsen, C., Rimmer, V.R., Hopkin, S.P., Weeks, J.M., 2000. Relative sensitivity of life-cycle and biomarker responses in four earthworm species exposed to zinc. Environ. Toxicol. Chem. 19, 1800-1808.

Solomon, M.E., 1949. The natural control of animal populations. J. Anim. Ecol. 18,1-35.

Taylor, A.R., Taylor, A.F.S., 2014. Assessing daily egestion rates in earthworms: using fungal spores as a natural soil marker to estimate gut transit time. Biol. Fert. Soils 50, 179-183.

van Genuchten, M.Th., 1980. A closed-form equation for predicting the hydraulic conductivity of unsaturated soils. Soil Sci. Soc. Am. J. 44, 892-898.

Wang, L., Shahbazi, A., Hanna, M.A., 2011. Characterisation of corn stover, distiller grains and cattle manure for thermochemical conversion. Biomass Bioenerg 35, 171-178.

Wilensky, U., 1999. NetLogo. Center for Connected Learning and Computer-Based Modeling. Northwestern University, Evanston, IL. http://ccl.northwestern.edu/ netlogo/. 